\title{
РЕГИОНАЛЬНАЯ ИНЖЕНЕРНАЯ ОЦЕНКА РЕЛЬЕФА РАЙОНА ПРОХОЖДЕНИЯ ПРОЕКТИРУЕМОГО ГАЗОПРОВОДА В САРАТОВСКОЙ ОБЛАСТИ
}

\author{
Черноморец Лев Сергеевич, \\ mrblacksea@mail.ru \\ Московский государственный университет им. М.В. Ломоносова, \\ Россия, 119991, г. Москва, Ленинские горы, 1.
}

\begin{abstract}
Актуальность исследования определяется недостаточной изученностью отношений между рельефообразованием и строительством газотранспортных систем. Решение научно-прикладных задач инженерной деятельности, таких как выбор оптимальной трассы для трубопроводов, проектирование мероприятий по инженерной защите сооружений и рекультивации земель, планирование мониторинга участков газотранспортных систем, требует оценки инженерно-геоморфологических условий. Данное исследование представляет собой опыт выполнения такой оценки на региональном уровне.

Целью работы является выполнение региональной инженерно-геоморфологической оценки района прохождения газотранспортных систем (на примере участка проектируемого газопровода в Саратовской области). Оценивание проводилось по морфометрическим, морфолитологическим, морфодинамическим и смешанным критериям, применимым на региональном масштабном уровне.

Основные методы: картографический метод, сравнительно-географический метод, полевое геоморфологическое и ландшафтное картографирование, морфометрический и статистический анализ, морфолитогенетический анализ, геоинформационный анализ (с использованием материалов радарной съемки рельефа SRTM), дешифрирование космических снимков. Графические и расчетные построения выполнялись с помощью программ MS Office, ArcGIS, AutoCAD и Global Mapper.

Результаты. Была проведена региональная инженерная оценка рельефа для участка размещения газотранспортных систем в Саратовской области. На объекте, выбранном для региональной оценки, наиболее сложные в инженерно-геоморфологическом отношении участки представлены на переходах долин рек. Склоны и днища долин, чередующиеся с междуречными пространствами, определяют дифференциацию трассы по морфолитологическим и морфодинамическим условиям. Северная часть территории прохождения трассы более благоприятна с точки зрения расчлененности рельефа. В то же время на юге (в Лысогорском районе) имеется более развитая транспортная инфраструктура.
\end{abstract}

\section{Ключевые слова:}

Инженерно-геоморфологическая оценка, критерии оценки рельефа, газотранспортные системы, строительство газопроводов, рельеф Саратовской области.

\section{Введение}

Вопросы оценок территории и, в частности, рельефа разрабатываются для разных видов природопользования. Отмечают несколько тенденций в применении оценок в географии и геоморфологии: стремление к сокращению числа показателей оценки путем выделения из них ведущих, предпочтение количественных показателей качественным и сведение элементарных показателей в комплексные.

Удаленность газовых месторождений от потребителя вызывает необходимость строительства магистральных газопроводов, предназначенных для перемещения газа из районов добычи к пунктам потребления. Они образуют газотранспортные системы (ГТС).

Рельеф территории оказывает влияние на строительство ГТС. Накопленный опыт по строительству трубопроводных систем в России и за рубежом также указывает на необходимость учета инженерно-геоморфологических особенностей территории, что отражено в отраслевой нормативной документации [1-3] и научно-практической литературе [4-15].

С.Б. Кузьмин [7] отмечает необходимость оценки геоморфологических процессов и риска природопользования на разных пространственно-таксономических уровнях, однако указывает на невоз- можность сделать это на единой критериальной основе. Поэтому набор применимых критериев инженерно-геоморфологической оценки по разным группам (морфометрические, морфолитологические, морфодинамические, смешанные) зависит от уровня рассмотрения - мелкомасштабного, регионального или локального [15].

Целью настоящей работы является выполнение региональной инженерно-геоморфологической оценки района прохождения ГТС (на примере участка проектируемого газопровода в Саратовской области). Подобная оценка по частным критериям может быть использована для:

- проектирования мероприятий по инженерной подготовке территории к строительству;

- выявления участков, требующих специальных мер инженерной защиты;

- проектирования мероприятий по рекультивации нарушенных земель;

- оптимизации экологического мониторинга и контроля при строительстве и эксплуатации сооружений, а также решения многих других задач.

Исследование основано на материалах собственных полевых геолого-геоморфологических исследований автора и его коллег на объекте, а также литературных и фондовых данных (в том числе, материалах радарных съемок рельефа 
SRTM и GTOPO30). Графические и расчетные построения выполнены с помощью пакета MS Office, а также программ ArcGIS, AutoCAD и Global Mapper.

\section{Объект исследования}

В качестве объекта региональной инженерной оценки рельефа был выбран участок проектируемого магистрального газопровода в Саратовской области (рис. 1).

Проектируемый газопровод расположен в пределах (с севера на юг, по ходу газа) Петровского, Аткарского, Татищевского и Лысогорского муниципальных районов.

В пределах области участок газопровода имеет длину около $170 \mathrm{kм} \mathrm{и} \mathrm{приурочен} \mathrm{к} \mathrm{восточному}$ крылу Воронежской антеклизы Восточно-Европейской платформы. Ее фундамент сложен гнейсами, гранитами, кристаллическими сланцами. Он имеет ступенчатое строение, меняя глубину залегания с северо-запада на юго-восток от 1 до 12-13 км [16]. Участок находится в поле амплитуд новейших тектонических движений от 200 до 500 м. Современные вертикальные движения имеют тенденцию к несильному (до 4 мм/год) опусканию [17].

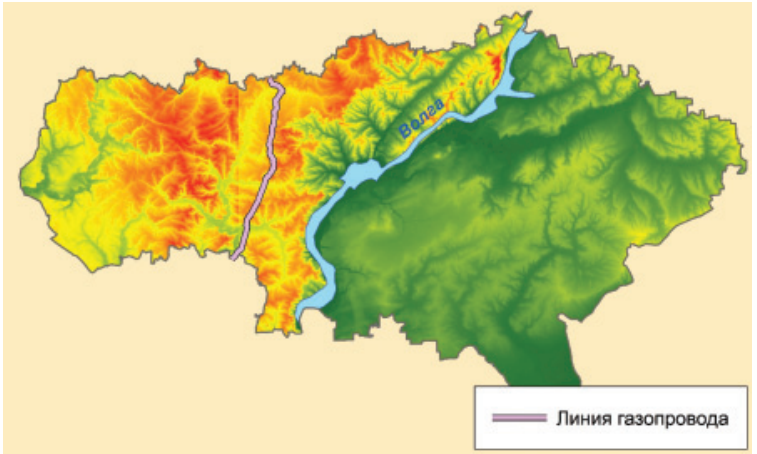

Рис. 1. Положение участка трассы проектируемого газопро вода в пределах Саратовской области (цветом обозначены высоты в непрерывной шкале от наибольших к наименьшим по возрастанию теплоты тона)

Fig. 1. Location of the projected gas pipeline route within the Saratov region (the color represents height in a continuous scale from lowest to highest in ascending order of warmth of tone)

Четвертичные отложения Саратовской области характеризуются небольшой мощностью, представлены аллювиальными (песок, галечник, супеси, суглинки), морскими (глина, песок), ледниковыми (суглинки, глины с валунами) и водноледниковыми (пески) образованиями. Граница максимального (днепровского) оледенения проходит по восточному борту долины р. Медведица [18] и не достигает трассы проектируемого газопровода, не доходя до нее около 30 км.

Оценка выполнялась в пределах «зоны возможного влияния» (ЗВВ), которой считалась трехкилометровая полоса по 1,5 км в обе стороны от оси газопровода.

\section{Методы исследования и обсуждение результатов}

Для инженерно-геоморфологической оценки на региональном масштабном уровне были выбраны следующие критерии:

- морфолитологические (свойства поверхностных грунтов);

- морфометрические (уклоны, расчлененность территории);

- морфодинамические (развитие опасных экзогенных процессов);

- смешанные (техногенный рельеф: транспортная инфраструктура).

\section{Оценка по морфолитологическим критериям}

Учет литологических особенностей территории на среднем масштабе (на уровне субъекта РФ) без использования материалов инженерных изысканий можно провести лишь в обобщенном виде. Среднемасштабные геологические карты не всегда могут дать информацию о конкретных участках вдоль трассы газопровода, на которых встречаются неустойчивые, размываемые или карстующиеся грунты.

В соответствии с картой четвертичных отложений из Атласа Саратовской области [18] вдоль трассы проектируемого газопровода (ПГ) представлены аллювиальные (пески, суглинки, глины), элювиально-делювиальные (суглинки, щебень) отложения и дочетвертичные породы (палеогеновые пески, песчаники, опоки, глины). Аллювиальные отложения в значительных количествах встречаются в долинах рек. Палеогеновые осадки отмечаются на приводораздельных частях структурных останцов междуречий. Элювиально-делювиальные отложения покрывают остальную часть пространств между долинами.

Наложение контуров с карты четвертичных отложений на ЗВВ позволило произвести сегментацию трассы по литологическим условиям на районы трех типов (рис. 2), которым соответствуют определенные комплексы рельефа:

1) дочетвертичные отложения под приводораздельными поверхностями междуречий - $95 \mathrm{kм}^{2}$ в пределах ЗВВ (20 \% от общей площади);

2) нерасчлененные элювиально-делювиальные отложения (суглинки, щебень) на междуречьях и склонах речных долин - $306 \mathrm{\kappa м}^{2}$ в пределах 3ВB (66 \% от общей площади);

3) современные и верхнечетвертичные аллювиальные отложения (пески, суглинки, глины) в комплексах речных долин - 64 км² $^{2}(14 \%)$.

В результате было проведено типологическое районирование трассы: по контурам распространения четвертичных отложений выделено 18 районов ЗВВ с разными морфолитологическими условиями. Площадь выделенных районов очень из-

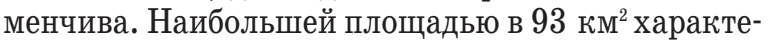
ризуется район 3 (нумерация с севера на юг по ходу газа, рис. 2) на междуречье рек Медведицы и Малого Колышлея, относящийся ко второму типу. Минимальная площадь имеет место в районе 
13 этого же типа (трасса пересекает его, однако он не проходит через ЗВВ целиком, будучи окруженным районом 12).

Меньше других в пределах 3ВВ (14 \% ) представлены по площади районы третьего типа. К таковым относятся районы 2, 6, 10, 15 и 17 (переходы трассы через Медведицу, Б. Колышлей, Идолгу, Карамыш и Большую Копенку соответственно).

Поскольку данное генерализованное районирование является по своей сути геоморфологическим, оно было использовано в дальнейшем при анализе по некоторым критериям других групп.

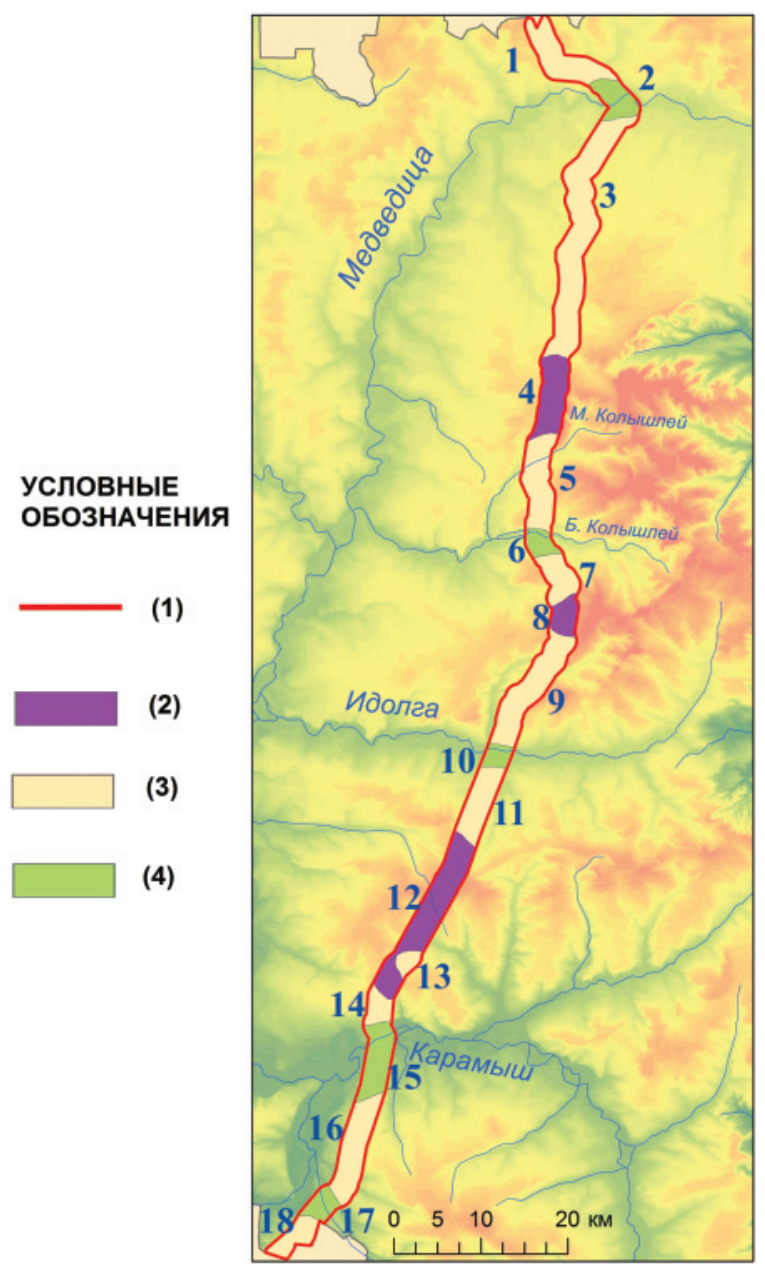

1 - зона возможного влияния (3ВВ)

2 - дочетвертичные отложения под приводораздельными поверхностями междуречий

3 - нерасчлененные элювиально-делювиальные отложения (суглинки, щебень) на междуречьях и склонах речных долин

4 - современные и верхнечетвертичные аллювиальные отложения (пески, суглинки, глины) в комплексах речных долин

Рис. 2. Типологическое районирование саратовского участка зоны возможного влияния трубопровода по морфолитологическим условиям строительства

Fig. 2. Typological zoning of the Saratov section of possible af fected area of the pipeline on morpholithological conditions for construction

Одной из основных целей оценки грунтов для строительства линейной части магистральных трубопроводов является выявление участков с грунтами, более или менее сложными для разработки. От физико-механических свойств грунтов зависит крутизна откосов траншей и котлованов.

Ряд источников, рассматривающих грунты с точки зрения трудности их разработки $[6,19,20$,$] ,$ свидетельствуют о наличии двух рядов возрастания сложности: 1) несвязные-связные-скальные и 2) сухие-влажные-мокрые грунты. В рамках региональной литологической оценки можно выделить относительно сложные и относительно простые участки, используя морфолитогенетический подход.

По характеру связности практически все поверхностные грунты вдоль трассы можно отнести к относительно простой (несвязные грунты) и, реже, осложненной категории (связные и скальные грунты). Так, грубообломочные карбонатные породы вскрываются иногда в днищах эрозионных форм. Такими примерами могут служить врезы в отвершках балок водосбора Б. Копенки (районы 16,17$)$ и на склоне долины Б. Колышлея (юг района 5). Участки с обводненными грунтами также распространены ограниченно и приурочены по большей части к поймам рек. Наиболее полно поймы в пределах трассы представлены у рек Медведица, Б. Колышлей, Идолга и Карамыш (районы $2,6,10$ и 15$)$.

\section{Оценка по морфометрическим критериям}

Для морфометрической оценки была построена серия карт. В первую очередь при морфометрических исследованиях чаще всего строится гипсометрическая карта территории.

Гипсометрическая карта построена по данным радарной топографической съемки SRTM разрешением около 90 м. Точность цифровой модели рельефа на основе съемки SRTM соответствует точности, применяющейся при создании карт масштаба 1:50000-1:100000 [21-23]. Для улучшения отображения пластики рельефа было выбрано сечение изолиний в $10 \mathrm{~m}$.

Диапазон абсолютных отметок вдоль трассы ПГ выявил 19 высотных интервалов (табл. 1).

Большая часть саратовского участка проходит по высотам 200-250 м. Смещенность распределения в сторону больших высот можно связать с тем, что выбор трассы обычно тяготеет к приводораздельным пространствам.

Линия проектируемого газопровода пересекает 36 водотоков, наиболее крупными из которых (с севера на юг) являются реки и речки: Медведица, Мокрая, Озерки, Малый и Большой Колышлей, Малая Идолга, Идолга, Сухая Двоенка, Карамыш, Большая и Малая Копенки, Мокрая Песковатка.

Анализ гипсометрической карты позволил выявить рад особенностей участка. Трасса практически целиком находится в бассейне р. Медведицы и по большей части проходит по ее левобережью субпараллельно простиранию долины, пересекая ее левые притоки и чередующиеся с ними междуречные пространства. 
Таблица 1. Распределение высот по интервалам вдоль трассы саратовского участка проектируемого газопровода

Table 1. Distribution of heights in intervals along the route of the Saratov section of the projected gas pipeline

\begin{tabular}{|c|c|c|}
\hline № & $\begin{array}{c}\text { Интервал высот, } \\
\text { Height range, } \mathrm{m}\end{array}$ & $\begin{array}{c}\text { Доля участков трассы } \\
\text { Percentage of route sections (\%) }\end{array}$ \\
\hline 1 & $<120$ & 0,1 \\
\hline 2 & $120-130$ & 3,2 \\
\hline 3 & $130-140$ & 1,1 \\
\hline 4 & $140-150$ & 2,3 \\
\hline 5 & $150-160$ & 4,5 \\
\hline 6 & $160-170$ & 3,4 \\
\hline 7 & $170-180$ & 3,1 \\
\hline 8 & $180-190$ & 5,6 \\
\hline 9 & $190-200$ & 6,5 \\
\hline 10 & $200-210$ & 8,2 \\
\hline 11 & $210-220$ & 12,5 \\
\hline 12 & $220-230$ & 9,8 \\
\hline 13 & $230-240$ & 11,6 \\
\hline 14 & $240-250$ & 9,0 \\
\hline 15 & $250-260$ & 6,6 \\
\hline 16 & $260-270$ & 8,2 \\
\hline 17 & $270-280$ & 2,7 \\
\hline 18 & $280-290$ & 1,7 \\
\hline 19 & $>290$ & 0,1 \\
\hline
\end{tabular}

Наибольшие абсолютные высоты вдоль линии газопровода представлены на междуречье Большого Колышлея и Малой Идолги (290 м). Минимальные высоты наблюдаются на переходе трубопровода через р. Карамыш (около 120 м).

По цифровой модели рельефа были рассчитаны уклоны в пределах ЗВВ проектируемого газопровода. Условия уклонов характеризовались согласно нормативным требованиям к строительству трубопроводов [1]. Оказалось удобным рассматривать карту уклонов совместно с гипсометрической. Параллельно для получения более полного представления об участках рассматривались привязанные топографические и космические снимки.

При анализе ЗВВ при данном разрешении модели не было обнаружено участков с очень сложными условиями строительства по уклонам. Осложненные по уклонам районы приурочены, как правило, к склонам долин рек и ручьев, попадающих в пределы ЗВВ. Такие участки встречаются в долинах Большого и Малого Колышлея, Малой Идолги, в верховьях р. Грязнухи в районе пересечения трассы с дорогой «Калининск-Саратов», в долине одного из истоков р. Сухой Двоенки.

Горизонтальная расчлененность (густота расчленения) рассчитывается как длина водотоков на единицу площади. Учитывая специфику исследуемого объекта (его линейность), было решено перейти от площадных параметров к линейным.

Саратовский участок трассы проектируемого газопровода был поделен на отрезки длиной 2 км. Затем с помощью инструментов анализа ArcGIS (Analysis Tools/Proximity/Buffer) были построены буферные зоны вокруг отрезков. Ширина буфер- ной зоны задавалась по 1,5 км в каждую сторону от трассы (в соответствии с шириной трехкилометровой полосы 3ВВ). Так были получены полигоны вдоль трассы примерной площадью $3 \times 2=6 \mathrm{kM}^{2}$ каждый.

Полуавтоматическим путем были рассчитаны длины водотоков в пределах каждого полигона, что при соотнесении с площадью дало значение густоты расчленения. Для удобства записи (чтобы значащие цифры располагались в разрядах целых и десятых долей) коэффициент расчлененности был выражен в километрах на км² (рис. 3).

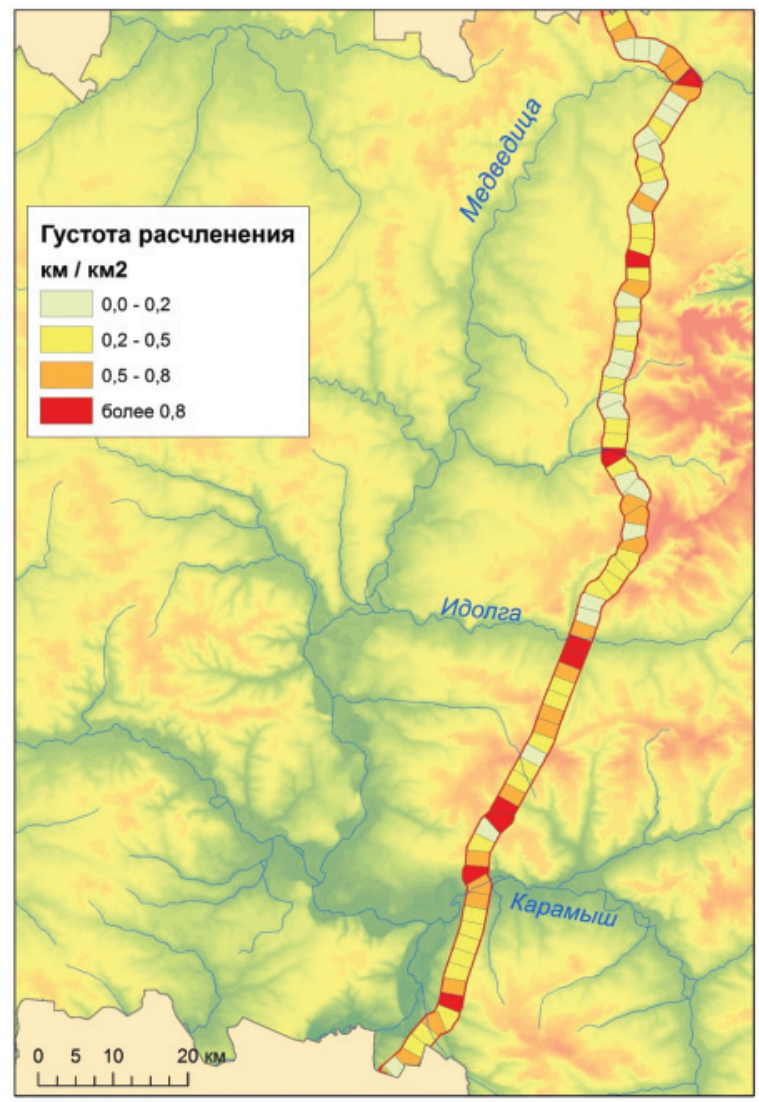

Рис. 3. Густота расчленения рельефа вдоль трассы саратовского участка проектируемого газопровода

Fig. 3. Horizontal terrain dissection along the route of the Saratov section of the projected gas pipeline

Средняя густота расчленения по всему саратовскому участку трассы составила $0,4 \mathrm{kм} / \mathrm{kM}^{2}$. Максимальная горизонтальная расчлененность $\left(1,1 \mathrm{kм} / \mathrm{KM}^{2}\right)$ зафиксирована к югу от р. Идолги на ее левобережье: здесь в ее долину открывается несколько эрозионных форм субпараллельно трассе. Высокая степень густоты расчленения наблюдается на нескольких участках в районе переходов ПГ через Медведицу, ручьи Мокрая и Озерки, Б. Колышлей, Идолгу, разветвленные верховья Сухой Двоенки, Карамыш и М. Копенку. Наименее расчлененные участки отмечены на междуречьях руч. Мокрая и p. Медведицы (к югу и юго-востоку от Петровска) и на междуречье руч. Озерки и р. Малый Колышлей. 


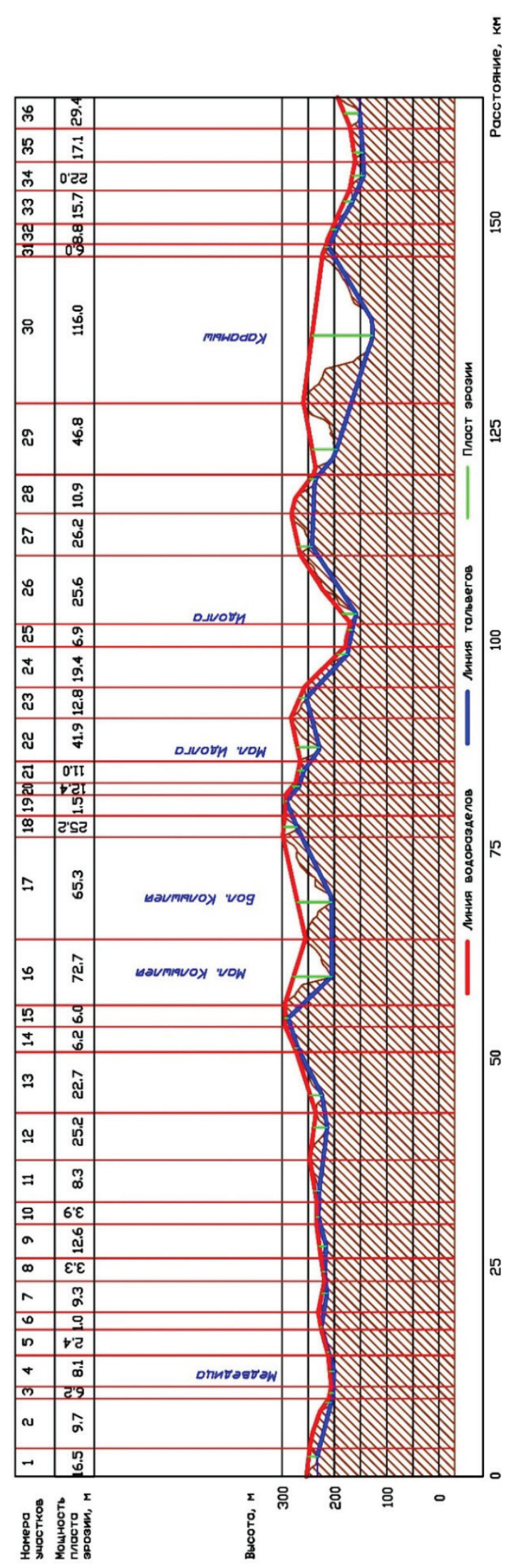

Рис. 4. Мощность пласта эрозии вдоль линии проектируемого газопровода в Саратовской области

Fig. 4. Thickness of the erosion layer along the route of the projected gas pipeline in the Saratov region
Для оценки вертикальной расчлененности (глубины расчленения) было решено воспользоваться методикой расчета пласта эрозии, разработанной И.С. Воскресенским под руководством профессоров С.С. Воскресенского, Г.С. Ананьева и д.г-м.н. В.П. Полеванова. Она использовалась C.C. Воскресенским для характеристики величины работы, проделанной эрозией совместно со склоноформирующими процессами [24]. Для удобства работы профиль строился по менее детальной цифровой модели рельефа (ЦМР), построенной по данным съемки GTOPO30 (разрешение 30 угловых секунд, или около 900 м).

Методика предполагает выделение на профиле водоразделов и тальвегов (точек соответственно максимума и минимума высот). По точкам происходит построение двух линий - линии водоразделов и линии тальвегов. Линии проводятся через все экстремумы профиля (и только через них), независимо от масштаба эрозионных форм. Исключением являются случаи, когда линии огибают рельеф, чтобы профиль не выходил за пространство между ними. Тогда они проходят по касательной к линии профиля. Расстояние между линией тальвегов и линией водоразделов в створе тальвега называется мощностью пласта эрозии $\left(\mathrm{M}_{\text {пэ }}, \mathrm{M}\right)$ на участке. Участки ограничиваются вертикалями, проходящими на профиле через точки водоразделов. Мощность пласта отражает глубину врезания данной эрозионной формы относительно ближайших междуречий.

Всего в пределах исследуемой территории было выделено 36 участков. Рассчитанный указанным способом пласт эрозии (рис. 4) изменяет свою мощность от 1 м к югу от долины р. Медведицы до 116 м в районе долины р. Карамыш.

Средняя величина превышения водоразделов над тальвегами составила около 20 м. В целом можно выделить два неравных района в пределах трассы: менее расчлененный северный, где мощность редко доходит до 25 м, и более расчлененный южный (от бровки долины Мал. Колышлея, уч. 15, 16). Южный район имеет максимальные показатели мощности пласта эрозии в долинах рек Б. и М. Колышлей, Идолга, М. Идолга и Карамыш, что вполне естественно. Особенно расчленена многочисленными и яркими оврагами его южная часть, в районе водосбора р. Б. Копенки (рис. 5).

\section{Оценка по морфодинамическим критериям}

В соответствии с Общим сейсмическим районированием ОСР-2015 В саратовский участок трассы ПГ расположен в ареале менее 6 баллов. Сейсмичность повышается к востоку от него (в районе долины р. Волги).

Тектоническая карта в Атласе Саратовской области [18] отражает отсутствие в пределах трассы и ЗВВ разломных зон. На карте новейшей тектоники [17] видно, что исследуемый участок находится в поле амплитуд новейших тектонических движений от 200 до 500 м. Иными словами, дан- 


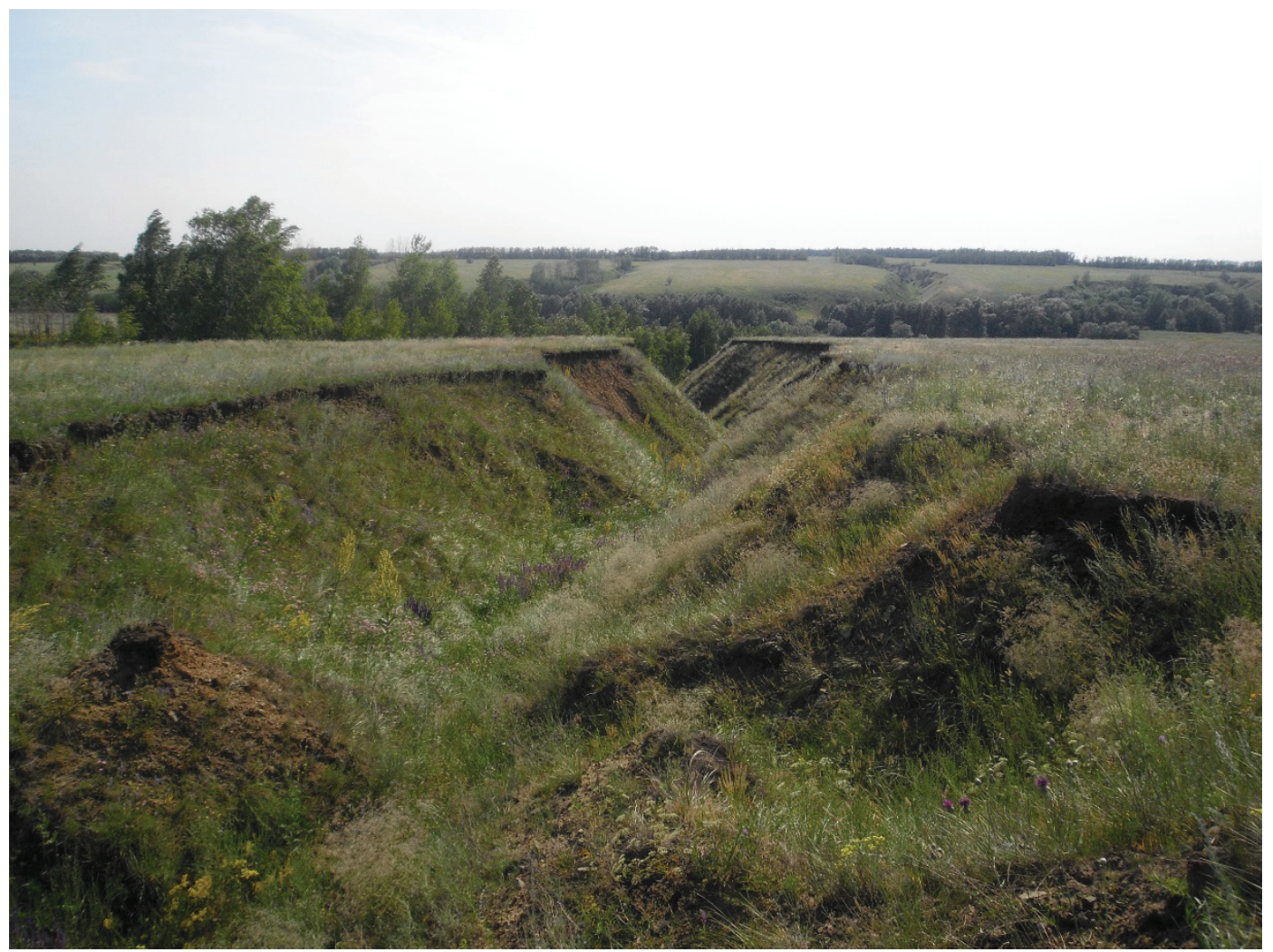

Рис. 5. Овраг в одном из притоков ручья Большая Копенка

Fig. 5. Ravine in one of the tributaries of the Bolshaya Kopenka stream

ная территория довольно медленно поднимается. Это позволяет предположить, что ведущая роль во взаимодействии трубопровода и рельефа будет принадлежать экзогенным, а не эндогенным процессам.

Инженерные изыскания, проводившиеся летом 2011 г. на территории саратовского участка ПГ, включали описание опасных экзогенных геоморфологических процессов и гидрогеологических явлений (ОЭГП и ГЯ). Описывались как действующие на сегодняшний день процессы, так и потенциальные (то обстоятельство, что на протяжении более половины своей длины трасса дублирует действующий газопровод, позволяет использовать метод аналогов для прогноза). Среди основных процессов и явлений были выделены:

- эрозионные (линейная и боковая эрозия);

- склоновые;

- суффозионно-просадочные;

- подтопление и затопление;

- заболачивание.

По собранным автором и его коллегами полевым материалам была составлена карта ОЭГП и ГЯ. При работе над ней использовались топографические карты масштаба 1:200000 и космические снимки разного разрешения.

Статистический анализ карты позволил оценить пораженность ЗВВ проектируемого газопровода опасными процессами и явлениями (путем со- отнесения площади контуров на составленной карте с площадью ЗВВ). Общая площадь ЗВВ составляет около 494,6 км². Области возможного проявления делювиального смыва и массового смещения обломочного чехла занимают $34,3 \mathrm{kм}^{2}$, или $6,9 \%$ от $3 \mathrm{BВ,} \mathrm{а} \mathrm{участки} \mathrm{возможного} \mathrm{развития} \mathrm{бло-}$ ковых движений на склонах - 5,7 км² $(1,2 \%)$. Суффозионно-просадочные явления при полевых изысканиях зафиксированы в 9 местах. Площадная пораженность территории опасными гидрогеологическими явлениями (процессами подтопления, затопления и заболачивания) составила $8,4 \mathrm{KM}^{2}(1,7 \%$ от $3 \mathrm{BB})$.

Общая длина эрозионных врезов по карте составила более 70 км. При этом большая часть врезов (73 вершины из 115) являются заросшими и/или неактивными. Активные («свежие») врезы составили $26,5 \%$ от общей длины. Тем не менее потенциальная активизация эрозии на стабилизировавшихся участках не исключается при начале строительства сооружения.

Области развития ОЭГП и ГЯ распределены в пределах трассы неравномерно. С севера и до долины Б. Колышлея опасные склоновые процессы проявляются незначительно, а участки с подтоплением, заболачиванием и эрозией локализованы в днищах долин протекающих в пределах 3ВВ водотоков (Тауза, Мокрая, Озерки и др.), а также отвершков овражно-балочной сети их водосборов. 


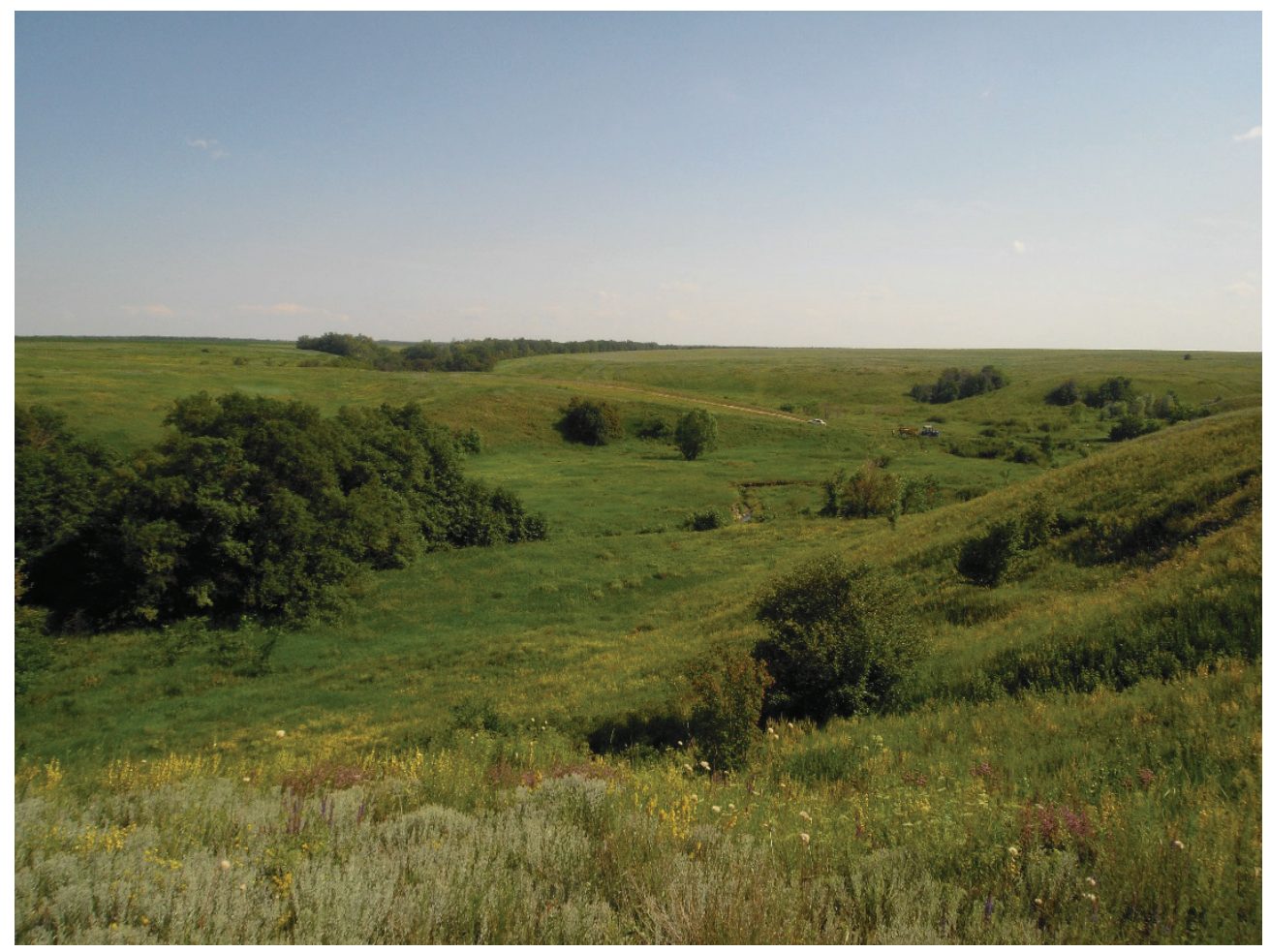

Pис. 6. Сложный овражно-балочный рельеф в верховьях р. Сухая Двоенка

Fig. 6. Complicated gully topography in the upper reaches of the Sukhaya Dvoyenka river

Максимальная протяженность пойменно-руслового комплекса вдоль трассы наблюдается у p. Медведицы (район 2, около 600 м). Для Большого Колышлея и Идолги (районы 6 и 10) данная величина составляет 450 и 300 м соответственно, а для Карамыша (район 15) она сравнительно невелика (около 80 м). Большая площадь флювиального морфолитологического комплекса, по которому выделен район 15 в пределах ЗВВ, связана в большей степени не с поймой, а с надпойменной террасой Карамыша.

В районе перехода через долину р. Идолги (район 10) активнее всего развито подтопление и заболачивание (22\% в пределах района). Участком ЗВВ с наибольшим развитием ОЭГП и ГЯ является ее южная часть, в особенности расчлененные многочисленными оврагами борта р. Бол. Копенки (рис. 6, районы 16-18). Достаточно сложными участками являются овраги в верховьях Сухой Двоенки (район 12) и склоны долины Мокрой Песковатки (район 18).

\section{Оценка по смешанным критериям}

(учет транспортной инфраструктуры)

Ряд исследователей рассматривает здания и сооружения как результаты антропогенного или техногенного рельефообразования $[25,26]$. Традиционным аргументом в пользу отнесения их к рельефу является то, что здания и сооружения, а также преобразованные поверхности естественного рельефа выполняют те же функции, что и ре- льеф в природно-территориальных комплексах. Это особенно заметно в крупных городах, где здания очень сильно влияют на микроклимат, ветровые потоки, поверхностный сток и т. д.

Дороги (железные и автомобильные) можно рассматривать в качестве специфических форм рельефа техногенного генезиса. В частности, их протяженность является морфологической (морфометрической) характеристикой, которая по этим основаниям может быть учтена в качестве критерия инженерной оценки рельефа.

Поэтому было решено проанализировать условия транспортной доступности района прохождения трассы. При этом для разделения трассы использовались единицы административно-территориального деления.

Кроме оценки территории, в пределах которой непосредственно производится строительство сооружений, важно учитывать необходимость доставки к ней материалов, строительной техники и рабочих. Доставка труб осуществляется в основном железнодорожным (полувагоны, трубоплатформы) и автомобильным (оборудованным, необорудованным) транспортом.

Подходящие к линии проектируемого газопровода трассы автомобильных и железных дорог, а также наблюдаемые вдольтрассовые проезды существующего газопровода дешифрировались по космическим снимкам разного разрешения.

Для обеспечения доступа к трассе при строительстве и при дальнейшей эксплуатации маги- 
стральных трубопроводов часто формируются вдольтрассовые проезды. Поскольку большая часть трассы была расположена в коридоре существующего газопровода «Починки-Изобильное», на большом протяжении (всего около 110 км от трассы) они уже имелись.

Таблица 2. Количество подьездов дорог к трассе ПГ и протяженность вдольтрассовых проездов по районам Саратовской области

Table 2. Number of road entrances to the route of the designed gas pipeline and the length of the service driveways by districts of the Saratov region

\begin{tabular}{|c|c|c|c|}
\hline 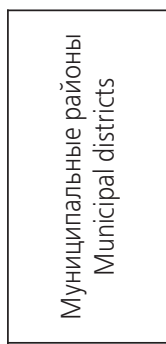 & 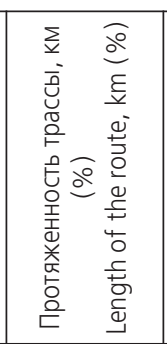 & 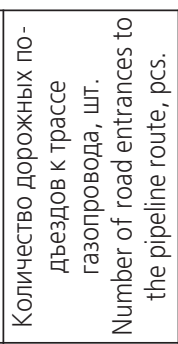 & 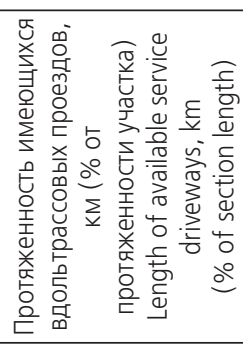 \\
\hline $\begin{array}{l}\text { Петровский } \\
\text { Petrovsky }\end{array}$ & $59,4(35,7)$ & 7 & $17,9(30,1)$ \\
\hline \begin{tabular}{|l|} 
Aткарский \\
Atkarsky
\end{tabular} & $18,0(10,8)$ & 1 & $11,9(66,1)$ \\
\hline $\begin{array}{l}\text { Татищевский } \\
\text { Tatischevsky }\end{array}$ & $32,5(19,5)$ & 2 & $28,7(88,4)$ \\
\hline $\begin{array}{l}\text { Лысогорский } \\
\text { Lysogorsky }\end{array}$ & $56,4(33,9)$ & 7 & $51,3(90,9)$ \\
\hline \begin{tabular}{|l} 
Bcero \\
Total
\end{tabular} & $166,3(100,0)$ & 17 & $109,7(66,0)$ \\
\hline
\end{tabular}

\section{СПИСОК ЛИТЕРАТУРЫ}

1. СП 36.13330.2012 Магистральные трубопроводы. Актуализированная редакция СНиП 2.05.06-85*. - М.: Госстрой, 2013. $97 \mathrm{c.}$

2. СП 115.13330 .2016 Геофизика опасных природных воздействий. Актуализированная редакция СНиП 22-01-95. - М.: Минстрой России, 2016. -49 с.

3. IS0 13623:2009 «Petroleum and natural gas industries - Pipeline transportation systems», NEQ. - Switzerland, 2009. - 11 p.

4. Симонов Ю.Г., Кружалин В.И. Инженерная геоморфология. М.: МГУ, 1993. - 208 c.

5. Mohitpour M., Golshan H., Murray A. Pipeline Design \& Construction: a Practical Approach. $2^{\text {nd }}$ ed. - New York: ASME Press, 2003. $-656 \mathrm{p}$.

6. Волков А.В. Инженерно-геоморфологическая оценка условий строительства газотранспортных систем в Ленинградской области: автореф. дис. ... канд. геогр. наук. - М., 2009. - 24 с.

7. Кузьмин С.Б. Оценка риска природопользования для суб̆ъектов Российской Федерации // Геориск. - 2016. - № 2. C. $30-37$.

8. Abspoel L., Courage W., Dabekaussen W., de Bruijn R., Kruse H., Wiersma A.P., Hijma M.P., van den Heuvel F., van den Broeck W. Risk-based asset management: automated structural reliability assessment of geographically distributed pipeline networks for gas and water in the Netherlands // Structure and Infrastructure Engineering. - 2018. - V. 14. - № 7. - P. 928-940.

9. Aloqaily A. Cross Country Pipeline Risk Assessments and Mitigation Strategies. - Houston: Gulf Professional Publishing, 2018. $198 \mathrm{p}$.
Железнодорожные трассы пересекают линии проектируемого газопровода в двух местах - в долинах рек Медведицы (Петровский район) и Малой Идолги (Татищевский район). Данные по количеству подъездов автодорог к проектируемому газопроводу (пересечений его с автодорогами), а также по протяженности вдольтрассовых проездов сведены в табл. 2 .

Из таблицы видно, что уже имеющимися вдольтрассовыми проездами более всего обеспечен участок трассы в Лысогорском районе (южная часть саратовского сектора трассы). На нем же зафиксирована и наибольшая плотность подъездов автодорог (в среднем примерно 1 подъезд на 8 км).

\section{Заключение}

На объекте, выбранном для региональной оценки рельефа (проектируемый газопровод в Саратовской области), наиболее сложные в инженерно-геоморфологическом отношении участки представлены на переходах через долины рр. Медведица, Б. Колышлей, Идолга и Карамыш. Комплексы рельефа (склоны и днища долин, чередующиеся с междуречными пространствами) определяют дифференциацию по литологическим и морфодинамическим условиям вдоль трассы. Оценивание по морфометрическим критериям обнаруживает дополнительно, что северная часть территории прохождения трассы более благоприятна с точки зрения расчлененности рельефа. В то же время южная часть трассы (в Лысогорском районе) имеет более развитую транспортную инфраструктуру (в большей степени обеспечена вдольтрассовыми проездами).

10. Risk Assessment of Long Gas and Oil Pipeline Projects Inducing Landslide Disasters during Construction / M. Bai, Y. Du, Y. Chen, Y. Xing, P. Zhao // Journal of Performance of Constructed Facilities. - 2017. - V. 31. - № 5. - P. 04017063 (1-7).

11. Ermolaeva A.V. Application of groundwater aggressiveness assessment method for estimation of the karst process at main gas pipeline construction // IOP Conference Series: Earth and Environmental Science. - 2016. - V. 33 - P. 012049 (1-7).

12. Erwin S.0., Schmidt J.C., Allred T.M. Post-project geomorphic assessment of a large process-based river restoration project // Geomorphology. - 2016. - V. 270. - P. 145-158.

13. Geach M. R., Stokes M., Hart A. The application of geomorphic indices in terrain analysis for ground engineering practice // Engineering Geology. - 2017. - V. 217. - P. 122-140.

14. Shabarchin 0., Tesfamariam S. Risk assessment of oil and gas pipelines with consideration of induced seismicity and internal corrosion // Journal of Loss Prevention in the Process Industries. 2017. - V. 47. - P. 85-94.

15. Черноморец Л.С. Критерии инженерной оценки рельефа при строительстве газотранспортных систем // Естественные и технические науки. - 2015. - № 9. - С. 81-87.

16. География Саратовской области / под ред. С.Г. Воскресенского. - Саратов: Детская книга, 1997. - 224 с.

17. Национальный атлас России. Т. 2. Природа и экология. - М.: Роскартография, 2007. - 495 с.

18. Атлас Саратовской области / под ред. В.Г. Лебедева. - М.: ГУГК, 1978. - 31 c.

19. Технология строительного производства / С.С. Атаев, Н.Н. Данилов, Б.В. Прыкин и др.. - М.: Стройиздат, 1984. - 559 с. 
20. ГОСТ 25100-2011 Грунты. Классификация. - М.: МНТКС, 2013. $-63 \mathrm{c}$.

21. Practical use of SRTM data in the tropics: Comparisons with digital elevation models generated from cartographic data / A. Jarvis, J. Rubiano, A. Nelson, A. Farrow, M. Mulligan. - Cali, C0: Centro Internacional de Agricultura Tropical (CIAT), 2004. $32 \mathrm{p}$.

22. Karwel A., Ewiak I. Estimation of the accuracy of the SRTM terrain model on the area of Poland // The International Archives of the Photogrammetry, Remote Sensing and Spatial Information Sciences. V. XXXVII, P. B7. - Beijing, 2008. - P. 169-172.

23. Карионов Ю.И. Оценка точности матрицы высот SRTM // Геопрофи. - 2010. - № 10. - С. 48-51.
24. Воскресенский С.С. Геоморфология Сибири (плоскогорья и низменности Восточной Сибири, горы Южной Сибири). - М.: МГУ, 1957. - 315 c.

25. Симонов Ю.Г., Симонова Т.Ю. Фундаментальные проблемы антропогенной геоморфологии // Геоморфология. - 2013. № 3. - C. 3-11.

26. Тимофеев Д.А. Рельефообразование природное и антропогенное: различия истинные и мнимые // Известия Российской академии наук. Серия географическая. - 1995. - № 6. C. $123-126$.

Поступила 10.09.2018 г.

\section{Информация об авторах}

Черномореи Л.С., соискатель кафедры геоморфологии и палеогеографии географического факультета Московского государственного университета им. М.В. Ломоносова. 
UDC 551.4.08

\title{
REGIONAL ENGINEERING ASSESSMENT OF THE RELIEF OF THE PROJECTED GAS PIPELINE AREA PASSAGE IN SARATOV REGION
}

\author{
Lev S. Chernomorets, \\ mrblacksea@mail.ru \\ Lomonosov Moscow State University, \\ 1, Leninskie Gory, 119991, Moscow, Russia.
}

The relevance of the research is caused by the lack of study of relations between relief and construction of gas transportation systems. The decision of scientific and applied engineering problems, such as choice of optimal route for pipelines, design of measures for engineering protection of facilities and land reclamation, planning of monitoring areas of gas transportation systems, requires an assessment of engineering and geomorphological conditions. This study represents regional-scaled experience of such an assessment.

The aim of this work is the regional engineering geomorphological assessment of the area of gas transportation systems passage (for example, the site of the proposed gas pipeline in the Saratov region). The assessment was carried out by morphometric, morpholithologic, morphodynamic and complex criteria applicable at the regional scale level.

Methods: cartographic method, comparative-geographical method, field geomorphological and landscape mapping, morphometric and statistical analysis, morpholithogenesis analysis, GIS analysis (using radar digital topographic database SRTM), interpretation of space images. Graphics and design build was performed by using MS Office, ArCGIS, AutoCAD and Global Mapper.

Results. The author has carried out regional engineering assessment of the relief for the route of gas transportation systems in Saratov region. At the site selected for regional assessment, the most difficult geomorphological areas are presented at the crossings of river valleys. The slopes and bottoms of the valleys, alternating with the watershed areas, determine the route differentiation by morpholithological and morphodynamic conditions. The Northern part of the territory is more favorable in terms of the terrain dissection along the route. At the same time, in the South (in the Lysogorsky district) there is more developed transport infrastructure.

\section{Key words:}

Engineering and geomorphological assessment, relief estimation criteria, gas transportation system, gas pipeline construction, relief of Saratov region.

\section{REFERENCES}

1. SP 36.13330.2012 Magistralnye truboprovody [Main pipelines]. Actualized edition of SNiP 2.05.06-85*. Moscow, Gosstroy Publ., 2013.97 p.

2. SP 115.13330.2016 Geofizika opasnykh prirodnykh vozdeystviy [Geophysics of natural hazards]. Actualized edition of SNiP 22-01-95. Moscow, Minstroy Rossii Publ., 2016. 49 p.

3. IS0 13623:2009 «Petroleum and natural gas industries - Pipeline transportation systems", NEQ. Switzerland, 2009. $11 \mathrm{p}$.

4. Simonov Yu.G., Kruzhalin V.I. Inzhenernaya geomorfologiya [Engineering geomorphology]. Moscow, MGU Publ., 1993. 208 p.

5. Mohitpour M., Golshan H., Murray A. Pipeline Design \& Construction: a Practical Approach. $2^{\text {nd }}$ ed. New York, ASME Press, $2003.656 \mathrm{p}$.

6. Volkov A.V. Inzhenerno-geomorfologicheskaya otsenka usloviy stroitelstva gazotransportnykh sistem $v$ Leningradskoy oblasti. Avtoreferat Dis. Kand. nauk [Engineering geomorphological assessment of conditions for gas transporting system construction in Leningrad Region. Cand. Diss. Abstract]. Moscow, 2009. 24 p.

7. Kuzmin S.B. Risk assessment for natural resource management in the subjects of Russian Federation. Georisk, 2016, no. 2, pp. 30-37. In Rus.

8. Abspoel L., Courage W., Dabekaussen W., de Bruijn R., Kruse H., Wiersma A.P., Hijma M.P., van den Heuvel F., van den Broeck W. Risk-based asset management: automated structural reliability assessment of geographically distributed pipeline networks for gas and water in the Netherlands. Structure and Infrastructure Engineering, 2018, vol. 14, no. 7, pp. 928-940.

9. Aloqaily A. Cross Country Pipeline Risk Assessments and Mitigation Strategies. Houston, Gulf Professional Publishing, 2018. $198 \mathrm{p}$.

10. Bai M., Du Y., Chen Y., Xing Y., Zhao P. Risk Assessment of Long Gas and Oil Pipeline Projects Inducing Landslide Disasters during Construction. Journal of Performance of Constructed Facilities, 2017, vol. 31, no. 5, p. 04017063 (1-7).
11. Ermolaeva A.V. Application of groundwater aggressiveness assessment method for estimation of the karst process at main gas pipeline construction. IOP Conference Series: Earth and Environmental Science, 2016, vol. 33, pp. 012049 (1-7).

12. Erwin S.0., Schmidt J.C., Allred T.M. Post-project geomorphic assessment of a large process-based river restoration project. Geomorphology, 2016, vol. 270, pp. 145-158.

13. Geach M.R., Stokes M., Hart A. The application of geomorphic indices in terrain analysis for ground engineering practice. Engineering Geology, 2017, vol. 217, pp. 122-140.

14. Shabarchin 0., Tesfamariam S. Risk assessment of oil and gas pipelines with consideration of induced seismicity and internal corrosion. Journal of Loss Prevention in the Process Industries, 2017, vol. 47, pp. 85-94.

15. Chernomorets L.S. Criteria for engineering evaluation of relief in construction of gas pipeline systems. Natural and technical Sciences, 2015, no. 9, pp. 81-87. In Rus.

16. Geografiya Saratouskoy oblasti [Geography of the Saratov Region]. Ed. by S.G. Voskresenky. Saratov, Detskaya Kniga Publ., 1997. $224 \mathrm{p}$.

17. Natsionalny atlas Rossii. T. 2. Priroda i ekologiya [National Atlas of Russia. V. 2. Nature and Environment]. Moscow, Roskartographiya Publ., 2008. $495 \mathrm{p}$.

18. Atlas Saratovskoy oblasti [Atlas of the Saratov region]. Ed. by V.G. Lebedev. Moscow, GUGK Publ., 1978. 31 p.

19. Ataev S.S., Danilov N.N., Prykin B. V. Tekhnologiya stroitelnogo proizvodstva [Construction technology]. Moscow, Stroyizdat Publ., 1984. 559 p.

20. GOST 25100-2011. Grunty. Klassifikatsiya [State Standard 25100-2011. Soils. Classification]. Moscow, MNTKS Publ., $2013.63 \mathrm{p}$.

21. Jarvis A., Rubiano J., Nelson A., Farrow A., Mulligan M. Practical use of SRTM data in the tropics: Comparisons with digital elevation models generated from cartographic data. Cali, C0, Centro Internacional de Agricultura Tropical (CIAT), 2004. 32 p. 
22. Karwel A., Ewiak I. Estimation of the accuracy of the SRTM terrain model on the area of Poland. The International Archives of the Photogrammetry, Remote Sensing and Spatial Information Sciences. Vol. XXXVII, P. B7. Beijing, 2008. pp. 169-172.

23. Karionov Yu.I. Otsenka tochnosti matritsy vysot SRTM [Evaluation of SRTM height matrix accuracy]. Geoprofi, 2010, no. 10, pp. 48-51. In Rus.

24. Voskresensky S.S. Geomorfologiya Sibiri (ploskogorya i nizmennosti Vostochnoy Sibiri, gory Yuzhnoy Sibiri) [Geomorphology of Siberia (plateaus and lowlands of Eastern Siberia, mountains of Southern Siberia)]. Moscow, Moscow State University Publ., 1957. $315 \mathrm{p}$.

\section{Information about the authors}

Lev S. Chernomorets, applicant, Lomonosov Moscow State University.
25. Simonov Yu.G., Simonova T.Yu. Fundamental problems of anthropogenic geomorphology. Geomorphology, 2013, no. 3, pp.3-11. In Rus.

26. Timofeev D.A. Relefoobrazovanie prirodnoe $i$ antropogennoe: razlichiya istinnye i mnimye [Natural and anthropogenic relief formation: true and imaginary differences]. Bulletin of the Russian Academy of Sciences. Geographical series, 1995, no. 6, pp. 124-126.

Received: 10 September 2018. 